\title{
Status consciousness and knowledge as potential impediments of households' sustainable consumption practices of fresh produce amidst times of climate change
}

\author{
Nadene JMM Marx-Pienaar \\ Department of Consumer Science, University of Pretoria, Pretoria, South Africa, 0002 \\ Tel: +27 (0)124205988 \\ Fax: +27(0)12420 2855 \\ E-mail: nadene.marxp@up.ac.za \\ Alet C. Erasmus \\ Department of Consumer Science, University of Pretoria, Pretoria, South Africa, 0002 \\ Tel: $+27(0) 124202575$ \\ Mobile: 0827842467 \\ Fax: $+27(0) 124202855$ \\ E-mail: alet.erasmus@up.ac.za
}

\begin{abstract}
Climate change is an issue recognised not only by developed countries but also emerging economies such as South Africa (SA). With the number one trend for 2014, 'limiting food waste' is proclaimed key in curbing climate change. In SA $31 \%$ of food, mostly fresh produce is wasted annually notwithstanding that more sustainable consumption of this commodity could address local food security and combat the global challenge of climate change. The purpose of this study was to produce evidence that an improvement of SA consumers' level of knowledge of climate change and subsequent consumption practices in this basic product category has great potential to mitigate climate change. A self-completion survey was used to collect data from 560 Tshwane households (a major urban area in SA).Amongst other issues relating to climate change and irresponsible consumer behaviour the survey also addressed the pertinent influence of consumer knowledge (tacit and explicit) and personal values such as status consciousness during
\end{abstract}


respondents' fresh produce consumption.Findings confirmed the influence of status consciousness when purchasing fresh produce among young consumers. This is alarming if one considers this groups' role in future endeavors. In terms of consumers' knowledge evidence suggests that much can still be done to educate all consumers not only about climate change per se but also about possible avenues that could be utilized to amend unsustainable consumption. Although findings conclusively confirmed that consumers fail to comprehend the implication of their un-realistic demands on retail, it was also evident that the mitigation of unsustainable behaviour could benefit from more support from retail and government.

\section{BACKGROUND}

Climate change has become a priority concern on the agenda of major organisations world-wide (Walker and King 2008:24; Kemp et al. 2010). Bleak forecasts of severe shortfalls in food supply and drinkable water in certain parts of the world are used to caution mankind about the consequences of negligent consumption (McGregor 2006; Nahman et al. 2012; WWF-Report 2012) indicating that affluent communities are the main culprits while the poor will suffer the most, as extreme changes in weather conditions will threaten those who depend on agriculture for their livelihood (Le Roux 2007; World Bank 2013). Unfortunately consumers are not necessarily aware that their consumption practices are destructive and that on a very basic level, their wastage of a, everyday commodity such as fresh produce might have dire consequences for our ecosystem (Hammett 2010; WWF-Report 2012).

In reality, consumers' over consumption and waste of fresh produce is sparked by retail practices, which, in a highly competitive market place, include the display loads of top quality, even exotic and imported out-ofseason fresh produce to attract and retain consumers' attention (D’Haese and Van Huylenbroeck 2005; ITCReport 2011; Marshak 2012). In consumers' minds, seasonal produce is therefore a foreign phenomenon because retailers' all year round display of an assortment of fresh produce has become the norm. Similarly, consumers are not necessarily aware that the production processes of convenience products such as pre-cut vegetables that have become highly sought after in modern households contribute to excessive waste that is not always utilised for other products (Stuart 2009:367; Marshak 2012; News24 2013). In a world of 
sophistication and convenience, consumers have become more self-centered and even believe that if they can afford certain luxuries, they deserve it, notwithstanding the implications (Schiffman and Kanuk 2010:358; Sivanathan and Petit 2010). This is especially true in terms of the growing wealth of the previously disadvantaged consumer groups in emerging economies such as South Africa (UNPDA 2007; Nieftagodien and Van der Berg 2007; Couth et al. 2011). World-wide, consumers strive to emulate the lifestyle and consumption patterns of an average American who embraces an American Dream of status and success (Simms, in Wills 2008) which, theoretically, would require requi the resources of more than three planets to maintain (Hanson and Zogby 2010).

Fuelled by powerful marketing campaigns, consumers' status related needs have therefore become a growing concern amongst environmental activists and researchers across diverse academic fields. Many proclaim that social responsibility needs to become the norm (McGregor 2000; Smith 2003) although it is particularly difficult to restrain consumers who aspire to improve their lifestyles and whose related personal goals, desires and status concerns do not demonstrate concern about the environment and contradict the principles of voluntary simplicity that is now propagated the ideal (O'Loughlin 2007).

Consumer concern relates to knowledge of the problem. Indications are that the more informed consumers are about climate change, the more willing they are to take remedial action (Sundblad, 2008). Unsustainable consumer behaviour can therefore be attributed to consumers either not having the facts regarding general environmental degradation, or having limited access to information regarding appropriate action strategies. Until recently, the concepts of tacit and explicit knowledge as dimensions of consumers' knowledge have received little attention. Explicit knowledge refers to factual information, for example consumers' knowledge regarding environmental aspects, such as the general condition of the ecology or fresh produce wastage figures. Tacit knowledge is a more intricate concept and involves underlying know-how and skills, for example, how to mitigate unsustainable behaviour (Jones and Leonard 2009). Households' consume fresh produce waste may therefore reflect a deficit of explicit and/ or tacit knowledge. 
Consumers may therefore firstly not grasp the problem and may secondly struggle not know how to resolve inappropriate consumption behaviour.

\section{RESEARCH AIMS AND THEORETIC PERSPECTIVE}

This study aimed to investigate and describe the influence of status consciousness, which may be a very potent driver of consumption in modern society, as well as consumers' explicit and tacit knowledge about the phenomenon of climate change on their households' purchasing and consumption practices of one of the most basic commodities in their homes, namely fresh produce. The study acknowledged the assumptions of both Anthony Giddens' structuration theory (Giddens 1984) and Spaargaren's social practices model.

Structuration theory follows a sociological-contextual approach and acknowledges the duality of the problem, i.e. the role of consumers' knowledge that is required to make sense of, and to direct their daily activities (Kaspersen 2000) as well industry's role in terms of efforts to mitigate climate change. This theory proposes that consumers, as the active agents of change, rely on their knowledge of a phenomenon and routinely 'reflexively monitor' their own behaviour as well as the contexts and settings surrounding them to better understand their behaviour and to enable them to explain and discuss it (Shields et al. 1996). This theory refers to society as a structure with pertinent rules and regulations that consumers have to abide with on a daily basis. In modern society this is part of the underlying problem because at present consumer society is largely driven by status and materialistic thinking that contradict the principles of sustainable consumption. In order to mitigate climate change, consumers need to re-evaluate the current social structure and to demonstrate willingness to promote change in all the domains of their existence. Rather than to enforce restrictions, consumers should be empowered as agents of change in the renewal of social structures that are dedicated to the cause and to instil a sense of moral and normative values that focus on societalrather than personal needs (Spaargaren 1997; Rose and Scheepers 2001). Reflexive monitoring of one's actions occurs at two levels of consciousness, namely discursive- and practical consciousness. Discursive consciousness refers to one's ability to explain and rationalise behaviour while practical consciousness refers to one's everyday knowledge about a phenomenon that incorporates a wealth of commonly accepted 
knowledge and everyday life skills. Although both levels of consciousness are relevant in consumers' behaviour, practical consciousness, i.e. consumers' habits and daily life, are more critical in understanding consumers' behaviour. In terms of mitigating unsustainable behaviour, discursive consciousness becomes essential for ultimate change (Kaspersen 2000).

\section{RESEARCH DESIGN AND METHODOLOGY}

A survey was done among consumers in a major metropolitan area in South Africa that allowed involvement of consumers of different socio economic levels who have access to the similar retail outlets. A structured questionnaire was composed with some self-developed questions, for example the demographic section and questions pertaining to consumers' purchasing practices. Other sections were based on existing scales that were slightly adapted to address the context of the investigation, namely fresh produce purchasing and consumption practices.

Consumers' status consciousness as potential personal and social drivers of consumption were investigated through eleven questions of which four questions were taken from Kilsheimers' (1993) status consumption scale. Four status items were extracted from Richins and Dawsons' (1992) materialism scale and three questions were self-designed. Questions were adapted to refer to the product of investigation rather than purchases in general. A four point Likert-type 'agreement' scale was used.

Consumers' explicit knowledge of climate change was investigated through 17 True/False questions that were drawn from Antil and Bennet 1979: Social responsible consumption scale (2 items); Stone, Barnes and Montgomery 1995: Eco scale (8 items); Dos Santos 2011 (1 item). To cover the topic of investigation six additional self-designed questions were included.

Two sections of the questionnaire were devoted to identify shortcomings in both dimension of consumers' knowledge (i.e. explicit and tacit) about issues related to climate change and sustainable consumption practices. Consumers' explicit knowledge of climate change was investigated through 17 True/False questions that were drawn from Antil and Bennet 1979: Social responsible consumption scale (2 items); Stone, Barnes and Montgomery 1995: Eco scale (8 items); Dos Santos 2011 (1 item). To cover the topic of 
investigation six additional self-designed questions were included. Consumers' tacit knowledge was investigated by means of 24 self-designed questions that requested responses on a four point Likert-type scale.

With the assistance of trained fieldworkers who were assigned to specific demographic areas across the city, a structured questionnaire was distributed among 700 households for self-completion on a drop-down-collect later basis. Within one month 560 completed questionnaires were retrieved. A pre-requisite for participation was an age limitation of at least 21 years, irrespective of gender and personal buying experience of fresh produce for their households during the foregoing month.

\section{DEMOGRAPHIC PROFILE OF THE SAMPLE}

The sample $(\mathrm{N}=560)$ mainly consisted of females $(\mathrm{n}=422 / 75.36 \%$; male: $\mathrm{n}=134 / 23.93 \%)$. The majority of the sample were younger that 50 years, with $40.89 \%(n=229)<30 ; 39.11 \%(n=219)$ between 30 and 50 years and 20\% $(\mathrm{n}=112)$ above 50 years. Different education levels were well represented: Grade 12 or lower: $\mathrm{n}=227 / 40.54 \%$; post secondary school qualification: $\mathrm{n}=333 / 60.47 \%$ ). The same applied for the income representation, namely middle income: $n=111 / 19.82 \%$; upper income categories: $n=203 / 36.08 \%$ ). The median income of the geographical area at the time reflected a typical middle income categorisation of R14 500 ZAR (COT 2011), while the median monthly household income for SA households stood at R9 169 ZAR (SAARF 2012; BMR 2012) [1 USD = 11.04 ZAR].

\section{DATA ANALYSIS AND RESULTS}

Data analysis included descriptive statistics, followed by exploratory factor analysis, ANOVA, post hoc tests, t-tests and Pearson correlations as required (Mazzocchi 2008:221). Cronbach's Alpha was calculated to verify the internal consistency of the responses throughout.

\section{Consumers' fresh produce purchase and subsequent wastage behaviour}

Respondents' purchasing practices revealed that the majority $(n=390 / 69.64 \%)$ preferred to purchase fresh produce in bulk packs, which was later disclosed as a prominent cause of unnecessary wastage. A notable percentage of the respondents who purchased fresh produce in smaller quantities $(n=253 / 45.18 \%)$ did so to 
limit waste. Although $66.54 \%(\mathrm{n}=372)$ of the respondents indicated that they plan fresh produce purchases in advance, $44.05 \%$ admitted that fresh produce is thrown away due to slow consumption. Some $(\mathrm{n}=219 /$ $39.20 \%$ ) admitted that they over purchase when products are cheap, while others $(n=184 / 33.77 \%)$ indicated that attractive displays tempt them to purchase more than needed and hence contribute to unnecessary wastage. Possibly the biggest reason for over consumption, which is difficult to address, is evidence that $43.10 \%(n=268)$ of the respondents tend to over purchase because they believe that fresh produce is healthy and subsequently tend to indulge. Realising that it may be unrealistic to expect zero wastage, respondents had to indicate how their households dispose of, or manage fresh produce waste. Findings indicated ignorance about sustainable disposal practices. Less than $25 \%$ of the respondents recycled through composting or optimised waste as bird and animal feed.

\section{Consumers' status consciousness as drivers of fresh produce consumption}

Cronbach Alphas for the eleven scale items varied between 0.789 and 0.844 , which confirmed the internal consistency of consumers' responses. An overall mean of 2.20 (Maximum $=4$ ) suggests that fresh produce purchases are not governed by status consciousness although certain purchase practices may be problematic. The means of four items were $>2.59$ to 2.82 , which suggest certain status related practices that are not consistent with social responsibility, i.e. $75.6 \%$ insisted on purchasing fresh produce irrespective of the season or the price; $67.1 \%$ felt entitled to the best produce because they deserved it for working hard, and $61.1 \%$ indicated that they will pay more for visually appealing produce, which seldom reflect sustainable consumption practices. Slightly blemished produce that would be perfect for a cooked dish are for example rejected and are eventually thrown away by retailers to meet consumers' demands for perfect produce. . Findings in Table 1 are presented in descending order. 
Table 1: Consumers' status consciousness

\begin{tabular}{|c|c|c|c|}
\hline Items & $\begin{array}{r}\text { Cronbach } \\
\text { Alpha }\end{array}$ & Mean* & $\begin{array}{r}\% \\
\text { Agreed }\end{array}$ \\
\hline $\begin{array}{l}\text { We place a lot of emphasis on the type of fresh produce when making a purchase } \\
\text { decision }\end{array}$ & .823 & 2.82 & 75.61 \\
\hline $\begin{array}{l}\text { We work very hard and therefore deserve that only the best fruit and vegetables are } \\
\text { made available in the stores that we visit }\end{array}$ & .813 & 2.76 & 67.10 \\
\hline We try to purchase only the most basic or simplest types of fresh produce** & .844 & 2.63 & 59.96 \\
\hline We would pay more for fresh produce that has a superior appearance & .820 & 2.59 & 61.08 \\
\hline We admire people who display fresh produce attractively in their kitchens & .806 & 2.36 & 49.66 \\
\hline $\begin{array}{l}\text { The type and quality of fresh produce that we purchase signifies how well we are } \\
\text { doing in life }\end{array}$ & .803 & 2.06 & 29.05 \\
\hline $\begin{array}{l}\text { We believe that an attractive bowl brimming with top quality fruit is an essential } \\
\text { part of our kitchen and will impress our family }\end{array}$ & .793 & 1.99 & 26.17 \\
\hline $\begin{array}{l}\text { We believe that an attractive bowl brimming with top quality fruit is an essential } \\
\text { part of our kitchen and will impress our friends }\end{array}$ & .789 & 1.94 & 21.23 \\
\hline $\begin{array}{l}\text { We are always on the lookout for exotic and imported fresh produce because we } \\
\text { believe it is of superior quality }\end{array}$ & .809 & 1.78 & 15.80 \\
\hline $\begin{array}{l}\text { Fresh produce that is imported is more attractive to us because it is admired by the } \\
\text { people }\end{array}$ & .797 & 1.65 & 11.36 \\
\hline We prefer to purchase imported products because they tend to have more status & .803 & 1.63 & 11.40 \\
\hline 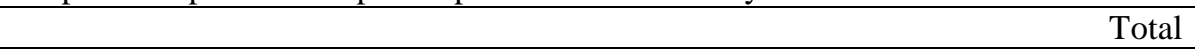 & - & 2.20 & 38.95 \\
\hline
\end{tabular}

$*=$ Mean maximum of $4 ; * *=$ Reverse coded items; Shaded items distinguish different levels of status consciousness

In terms of the status consciousness of various demographic sets of the sample, ANOVA was used to identify significant differences within the age, education level- and income level categories, while $\mathrm{T}-$ tests were performed to do the same for the gender and population category. Neither gender nor age seem to be significant indicators of status consciousness as a precursor of fresh produce purchase and consumption practices $\left(\right.$ Gender: $\mathrm{M}_{\mathrm{F}}=2.22 ; \mathrm{M}_{\mathrm{M}}=2.19 ; \mathrm{p}=0.550$. Age: $\mathrm{M}_{20-<30}=2.20 ; \mathrm{M}_{30-<50}=2.22 ; \mathrm{M}_{>50}=2.16 ; \mathrm{p}=$ $0.576)$.

Income theoretically determines spending power, but does not necessarily reflect status consumption (O'Cass and McEwen 2006). ANOVA exposed significant differences among the income categories $(\mathrm{p}=$ 0.001), which were specified through a subsequent post-hoc Bonferroni test. The lowest income group $(<R 10$ 000: $M=2.33)$ is significantly more inclined to purchase fresh produce for status related reasons than the two higher income groups $\left(\mathrm{M}_{>\mathrm{R} 10000-\mathrm{R} 25000}=2.11 ; \mathrm{M}_{\geq \mathrm{R} 25000}=2.11\right)$. Higher social aspirations probably explains their behaviour as the consumption behaviour of lower income consumers in particular, is often driven by status and or materialistic ideals, as they often splurge and consume conspicuously - even irrationally - for the purpose of personal satisfaction or the admiration of others (Belk 1988). In addition, 
"saving the planet" is a higher order need which is not necessarily a priority for low-income consumers (Nair 2011).

Findings suggested that consumers with the lowest level of education $(<$ grade 12$)$ are significantly more status conscious $(\mathrm{M}=2.84 ; \mathrm{p}=0.003)$ compared to higher educated consumers. Similarly consumers who have completed secondary school $(M=2.26)$ seem significantly more status conscious than consumers with a post-secondary school qualification $(\mathrm{M}=2.15 ; \mathrm{p}=0.026)$. Lower educated consumers are therefore significantly more status conscious and inclined to purchase fresh produce conspicuously. Literature corroborates these findings by reflecting that better educated consumers are more likely than those with less education to emphasise the importance of sustainable consumption in order to combat climate change (Patchen, 2006).

\section{Consumers' knowledge of climate change}

\section{Consumers' explicit knowledge}

Explicit knowledge about environmental issues refers to factual information, including relevant concepts that are required for a complete understanding of environmental problems and their causes as well as the consequences of such problems (Haron et al.2005:429). Factual information about climate changeis generally insufficient to alter ingrained behaviour (Nickols 2010), although it would instigate some willingness to adapt unsustainable behavioural practices based on insight about the problem. Findings are presented in Table 2 in descending order. 
Table 2: Consumers' explicit knowledge of climate change

\begin{tabular}{|c|c|c|}
\hline Knowledge & Item & $\%$ Correct** \\
\hline Excellent: & An increase in the SA population will put further strain on our natural resources & 91.19 \\
\hline $\mathrm{M}=>\mathbf{9 0 \%}$ & Saving electricity in our everyday living will contribute to saving the planet & 90.20 \\
\hline Very good: & Environmental pollution taking place in China does not have any impact on SA & 88.32 \\
\hline \multirow[t]{3}{*}{$M=80-<90 \%$} & $\begin{array}{l}\text { Pollution is currently one of the most critical problems in terms of the sustainability of } \\
\text { SA's natural resources }\end{array}$ & 87.68 \\
\hline & All locally produced products are environmentally friendly & 81.70 \\
\hline & The economic growth of SA is not influenced by environmental problems & 80.54 \\
\hline \multirow[t]{4}{*}{$\begin{array}{l}\text { Good: } \\
M=70-<80 \%\end{array}$} & $\begin{array}{l}\text { The earth's resources are infinite and should be used to the fullest to increase the } \\
\text { standard of living of all SA citizens }\end{array}$ & 75.05 \\
\hline & $\begin{array}{l}\text { The amount of energy used by my household does not have a significant impact on the } \\
\text { environment }\end{array}$ & 74.90 \\
\hline & Global warming is mostly caused by the sun radiating more heat & 72.58 \\
\hline & $\begin{array}{l}\text { My current purchases decisions will have consequences for product availability of future } \\
\text { generations }\end{array}$ & 72.38 \\
\hline \multirow{4}{*}{$\begin{array}{l}\text { Above } \\
\text { average: } \\
M=60-<70 \%\end{array}$} & The average citizen can do very little to reduce climate change & 69.98 \\
\hline & $\begin{array}{l}\text { Pollution does not affect me personally to the same extent that it affects fellow citizens in } \\
\text { SA }\end{array}$ & 68.16 \\
\hline & The USA is the biggest producer of gasses that contribute to air pollution & 67.10 \\
\hline & $\begin{array}{l}\text { Methane, which is largely responsible for the damage to the environment, is only emitted } \\
\text { by industrial equipment and cars which are powered by fossil fuels }\end{array}$ & 66.90 \\
\hline \multirow[t]{3}{*}{$\begin{array}{l}\text { Poor: } \\
M=<\mathbf{5 0 \%}\end{array}$} & $\begin{array}{l}\text { Organic materials like grass, food scraps and compost heaps do not emit greenhouse } \\
\text { gasses that are harmful to the environment }\end{array}$ & 45.79 \\
\hline & Climate change is a direct consequence of the hole in the ozone layer & 26.04 \\
\hline & Climate change is caused by the presence of greenhouse gasses in the air & 11.80 \\
\hline
\end{tabular}

$* *$ Mean Maximum of 100; Shaded items are areas of concern

Although results presented in Table 2 indicate that consumers' overall explicit knowledge of climate change is above average (>60\%), it is particularly disappointing that more than $30 \%$ of the respondents believed that the average citizen can do very little to reduce climate change, and that pollution does not affect them to the same extent that it affects others. Consumers' lack of explicit knowledge was evident when asked about contributors towards the emission of greenhouse gasses; causes of the hole in the ozone layer as well as the relevance of greenhouse gasses in terms of climate change. These are highly theoretical issues that need to be explained in more simplistic terms to the general public to improve their understanding of the problem. Critical areas of concern included evidence that almost $60 \%$ of respondents were unaware that food scraps also emit greenhouse gasses and therefore contribute to climate change. Consumers hence discard fresh produce without considering the consequences.

Findings pertaining to consumers' explicit knowledge across different demographic categories indicated significant differences among the different income and population groups. ANOVA indicated significant differences among the four income groups $(\mathrm{p}=0.000)$. A post hoc Bonferroni test indicated the two higher 
income groups' explicit knowledge was significantly better, i.e. $68.73 \%$ and $69.81 \%$ respectively compared to the two lower income groups that obtained approximately 60\%. Possible reasons for higher income consumers' significantly higher scores could probably be related to better access to information sources. A T-test disclosed a significant difference among the two population groups $(p=0.000)$, namely Whites' explicit knowledge was significantly higher $(65.84 \%)$ than the population groups $(54.97 \%)$. The Black population group in SA is currently the fastest growing economic segment. This is worrisome considering their lack of knowledge and implications for sustainable consumption.

\section{Consumers' tacit knowledge}

Exploratory factor analysis, specifically principal axis factoring was performed using a Varimax rotation with Kaizer normalisation and with Eigen values $>1$ to reduce the items in terms of coherent constructs. Five factors emerged, retaining 21 of the 24 original scale items and omitting three due to low communalities. Considering an acceptable norm of $>30 \%$, the total variance explained of almost $51 \%$, was interpreted as a good fit (Mazzocchi 2008:222). The Cronbach Alpha's of all factors except factor 5 were acceptable. Unfortunately factor 4 only contained two items, which is not ideal (Mazzocchi 2008:224). Therefore a Pearson correlation test was done. A value of 1 confirmed a positive correlation between the two items. Table 3 presents the content of the five factors and their relevant statistical values. 
Table 3: Dimensions of consumers' tacit knowledge

\begin{tabular}{|c|c|c|c|c|c|}
\hline \multirow{2}{*}{ Items } & \multicolumn{5}{|c|}{ Factors } \\
\hline & 1 & 2 & 3 & 4 & 5 \\
\hline $\begin{array}{l}\text { South African retailers should only sell fresh produce that is produced } \\
\text { locally }\end{array}$ & .582 & .032 & .089 & -.004 & .075 \\
\hline $\begin{array}{l}\text { Purchasing imported produce has consequences that contribute to } \\
\text { climate change }\end{array}$ & .477 & .148 & .177 & .244 & -.163 \\
\hline $\begin{array}{l}\text { Purchasing imported produce is negative for the economy of South } \\
\text { Africa }\end{array}$ & .623 & .059 & -.028 & .010 & .026 \\
\hline $\begin{array}{l}\text { Purchasing loose fruit without extra packaging signifies } \\
\text { environmentally friendly behaviour }\end{array}$ & .411 & .079 & .040 & .041 & .083 \\
\hline $\begin{array}{l}\text { We as consumers should not demand imported fresh produce in order } \\
\text { to demonstrate that we care about the environment }\end{array}$ & .542 & .036 & .282 & .172 & -.033 \\
\hline $\begin{array}{l}\text { Retailers could make more effort to keep consumers informed about } \\
\text { the environmental consequences of their purchases }\end{array}$ & .308 & .195 & .247 & -.087 & -.044 \\
\hline $\begin{array}{l}\text { Consumers need to purchase locally produced fresh produce rather than } \\
\text { imported fresh produce }\end{array}$ & .662 & .098 & .208 & -.102 & .039 \\
\hline $\begin{array}{l}\text { If one is really concerned about the environment, one should buy } \\
\text { locally produced fresh produce irrespective of the price }\end{array}$ & .383 & .167 & .215 & .279 & .156 \\
\hline $\begin{array}{l}\text { Purchasing pre-cut / pre-prepared fresh produce is recommended } \\
\text { because it reduces waste in general }\end{array}$ & -.053 & .316 & .023 & .235 & .070 \\
\hline $\begin{array}{l}\text { Growing a personal vegetable garden indicates that one is concerned } \\
\text { about the environment }\end{array}$ & .175 & .753 & .135 & -.008 & .055 \\
\hline $\begin{array}{l}\text { All consumers who have their own compost heaps are environmentally } \\
\text { conscious }\end{array}$ & .129 & .745 & .114 & -.016 & .133 \\
\hline $\begin{array}{l}\text { Limiting my household's fresh produce waste can make a noteworthy } \\
\text { difference in saving our planet }\end{array}$ & .218 & .512 & .223 & .054 & -.090 \\
\hline Fresh produce wastage is a neglected topic in our country & .235 & .110 & .329 & -.113 & -.041 \\
\hline $\begin{array}{l}\text { We as consumers need to tolerate lower stock volumes in stores to } \\
\text { limit fresh produce waste }\end{array}$ & .162 & .122 & 689 & -.072 & -.051 \\
\hline $\begin{array}{l}\text { We as consumers need to tolerate a smaller variety of fresh produce in } \\
\text { stores to demonstrate that we care about our environment }\end{array}$ & .023 & .141 & 688 & .213 & .054 \\
\hline $\begin{array}{l}\text { We as consumers need to tolerate fresh produce of a slightly lower } \\
\text { quality to demonstrate that we care about the environment }\end{array}$ & .209 & .084 & .415 & .248 & -.027 \\
\hline The surplus fresh produce at retailers is incinerated & -.047 & .011 & .025 & 676 & .033 \\
\hline The surplus fresh produce at retailers goes to landfills & .111 & .024 & .034 & .432 & .010 \\
\hline $\begin{array}{l}\text { The surplus fresh produce at retailers is put to good use by distributing } \\
\text { it to charity organisations }\end{array}$ & .176 & .107 & .067 & -.065 & .414 \\
\hline The surplus fresh produce at retailers is converted into useful compost & -.061 & .076 & -.105 & .242 & .562 \\
\hline Fresh produce waste is not harmful to the environment & .008 & -.028 & -.027 & -.017 & .508 \\
\hline Mean* & 2.78 & 2.81 & 2.67 & 2.28 & 2.86 \\
\hline Standard Deviation & .547 & .554 & .489 & .587 & .442 \\
\hline$\%$ Variance explained & 20.32 & 8.66 & 7.83 & $\mathbf{7 . 5 5}$ & 5.99 \\
\hline Cronbach Alpha & .748 & .699 & .624 & - & .452 \\
\hline Pearson correlation coefficient & - & - & - & 1 & \\
\hline
\end{tabular}

*Maximum: 4

A thorough investigation of the content facilitated the identification of factor labels, namely Factor 1:

Sustainable buying behaviour; Factor 2: Sustainable household behaviour; Factor 3: Sustainable consumer demands; Factor 4: Awareness of unsustainable retailing practices; Factor 5: Awareness of sustainable waste management. The factor means of Factors $1,2,3$ and $5(\mathrm{M}=\geq 2.67$ to 2.86$)$ suggest reasonable tacit knowledge levels that are conducive to mitigate unsustainable consumption behaviour. However, factor 4 results indicate that most respondents are not much concerned about unsustainable retailing practices $\left(\mathrm{M}_{\mathrm{F} 4}=\right.$ 2.28), which is critical in terms of escalating fresh produce waste (Gustavsson 2011; Gunders 2012). 
ANOVA was used to identify significant differences within the age, level of education and income categories, while T-tests were performed to investigate the gender and population category. Post-hoc tests were done to specify the differences explicitly.

Factor 1, Sustainable buying behaviour: The only significant difference detected was within the gender category. Females' tacit knowledge concerning sustainable buying behaviour $\left(\mathrm{M}_{\mathrm{F}}=2.89\right)$ was significantly higher than males' $\left(\mathrm{M}_{\mathrm{M}}=2.77 ; \mathrm{p}=0.005\right)$, confirming earlier findings in this study, namely that females still predominantly carry the responsibility as main purchasing agents.

Factor 2, Sustainable household behaviour: Significant differences were revealed within the gender, and the level of education categories. Females were significantly better informed than their male counterparts $\left(\mathrm{M}_{\mathrm{F}}=2.86 ; \mathrm{M}_{\mathrm{M}}: 2.64 ; \mathrm{p}=0.0001\right)$. These findings support arguments that women in Africa are powerful agents of change because they are not only prominent nurturers and socializing agents in their own households but also account for almost $80 \%$ of the continents' agricultural sector, which signify major potential for positive change (O'Connor et al. 1999; Nelson, 2011). A post-hoc Bonferroni test revealed the location of the significant differences among the different level of education groups' tacit knowledge about sustainable household consumption behaviour which contradict the findings of an American study (Patchen 2006). The lowest level of education groups' tacit knowledge $\left(\mathrm{M}_{\leq \mathrm{Gr} 12}=3.48\right)$ of sustainable household behaviour is significantly higher than the other two groups' $(M=2.74,2.86$; $(p=0.044)$. Lower educated consumers' knowledge is probably based on consumer socialisation rather than formal education.

Factor 3: Gender seemed to be the only significant predictor of sustainable consumer demands. Females tacit knowledge $\left(M_{F}=2.69\right)$ was significantly higher than males' $\left(M_{M}=2.59 ; p=0.044\right) . S$ ocial and cultural contexts often determine gender roles in society, which regulates access to information and influence subsequent consumer demands and behaviour (Salazar, Oerlemans and Stroe-Biezen 2013). Outcomes in this investigation might be due to females' primary responsibility for food procurement in their households. Findings nevertheless indicate much room for improvement as even females' knowledge was average $\left(\mathrm{M}_{\mathrm{Max}}\right.$ $=4)$. 
Factor 4: Consumers' awareness of unsustainable retailing practices could only be inferred in terms of two scale items (Table 3). A Pearson Chi-Square test could not confirm significant differences between males and females, but findings revealed a critical deficit in terms of knowledge about the wastage and disposal of fresh produce at retailers. Significant differences $(p=0.034)$ among the age groups were further explored, indicating that the youngest consumers ( $<30$ years of age) were significantly better informed than the rest, although scores were relatively low. $(\mathrm{M}=<2.5)$. Effort is therefore required to empower consumers to make informed judgements.

Factor 5: Neither of the demographic characteristics (gender, age, income level, education level or population group) seem to be significant predictors of consumers' tacit knowledge concerning sustainable waste management. Means across and within the sub sets of the various categories $(\mathrm{M}=2.73$ to 2.83$)$ suggest that consumers' knowledge is above average.

\section{CONCLUSIONS AND RECOMMENDATIONS}

Findings of this study indicated that consumers do not consciously consider society and/or the natural environment when purchasing, consuming and disposing of fresh produce. Although consumers do not seem status conscious, certain aspects of their fresh produce purchasing and consumption practices are typical of status consciousness, which are conducive to unsustainable behaviour. Females' behaviour is of particular concern because they are regarded as critical agents of change due to their primary responsibility for the procurement of their households' food supplies. Findings indicated that most females unfortunately select fresh produce based on visual appearance and prolonged sell-by-dates notwithstanding the consequences that their preferences might have on the creation of waste which is detrimental for the natural environment. Most respondents admitted that although they try to plan fresh produce purchases in advance, they often purchase more than they could consume and subsequently waste unnecessarily. Some blamed attractive displays in retail stores for their indulgence. The relative affordability of fresh produce was also indicated as a primary reason for excessive purchases. A critical area of concern is some consumers' belief that they are entitled to superior quality produce because their expectations of the service offering are vital in terms of retailers' 
strategies.

The investigation of the potential influence of status consciousness on consumers' purchasing behaviour indicated that the young and lower educated consumers tend to be more status conscious, even when purchasing a basic commodity such as fresh produce. This demonstrates little concern for fellow and future citizens, which is particularly concerning in the SA context because the majority of consumers fall in this group. Although not impressively so, findings indicate that females are not only less status conscious when purchasing fresh produce, but are also significantly more competent regarding the principles of sustainability than males. Based on their role in terms of the food procurement in their homes, their potential contribution to promote sustainable purchasing and consumption behaviour should be optimised.

Findings furthermore confirmed consumers' inability to reflexively monitor their behaviour in a way that would enhance pro-environmental behaviour. Current purchasing and disposal practices revealed shortcomings in consumers' practical consciousness, which is detrimental in terms of the sustainability of our natural resources. Points of contention are consumer demands concerning the visual appearance and availability of produce which are not realistic; the excessive waste of fresh produce and the improper disposal of waste.

Consumers' discursive consciousness, which is critical for change relied extensively on consumers' explicit and tacit knowledge. It is argued that the more informed consumers are about climate change and possible avenues of mitigation, the more willing they are to take remedial action to correct unsustainable consumer behaviour. Findings indicated discrepancies in terms of respondents' explicit and tacit knowledge about climate change and its relevance in terms of fresh produce consumption practices. Findings revealed that older, lower educated, lower income as well as consumers from the population group other than whites, lack explicit (factual) knowledge about climate change, despite possessing the tacit knowledge (skills and ability) that is required to purchase and consume in environmentally responsible ways. Lack of explicit knowledge does therefore not necessarily mean that consumers will act irresponsible. In the context of this study these findings are probably the result of limited financial resources and may therefore not necessarily indicate true concern about climate change. From a theoretical point of view, 'saving the planet' and honouring the 
principles of sustainable consumption are complex and reflects a higher order need, which many SA consumers might struggle to associate with even though they possess the knowledge and skills to do so. On the contrary, findings indicated that younger, better educated, higher income and White respondents lack tacit knowledge about sustainable consumption practices despite possessing ample explicit knowledge About the issue. These consumer groups apparently understand the urgency of the problem, but fail to demonstrate that through their everyday purchase and consumption practices. One causal factor may be their fast paced lifestyles, which often stimulate consumerist values and status consciousness.

Although alarming, the negligent behaviour of consumers who actually possess the explicit knowledge about climate change might probably be easier to change because when informed, they would understand the consequences of their behaviour and would more easily be able to reflexively monitor their behavioural practices. Efforts to mitigate consumers' unsustainable behaviour rely on consumers' discursive consciousness, which is more achievable in this instance compared to consumers who lack explicit knowledge.

Although it would be easier to change consumers' behaviour if they possess the required explicit knowledge about climate change, it should be noted that the majority of SA consumers who lack explicit knowledge but possess the tacit knowledge, are amongst the most vulnerable in society and could hence be guided towards a positive outcome. These consumers' could be empowered to understand the consequences of their consumption which already reflect desirable behaviour. Changing consumer behaviour is far from easy. In SA the situation is even more problematic as the country endorses eleven official languages, provide home for numerous social cultures and is experiencing major educational challenges. For many previously disadvantaged consumer groups, rectifying an asset deficit and improving their lifestyle have become primary objectives in their lives. Willingness to commit to sustainable purchasing and consumption practices therefore require a major mind shift. Unfortunately desperate times call for desperate measures and despite the complexity of the matter, efforts should continue to involve consumers in a plea to save. 


\section{REFERENCES}

Antil, John.T. \& Bennett, Peter. 1979. Construction and validation of a scale to measure socially responsible consumption behaviour. In Bearden, W.O. \&Netemeyer, R.G. Handbook of Marketing Scales: Multi-Item measures for marketing and consumer. 1999. Sage. California.

Belk, Russel. 1988. Possessions and the Extended Self. Journal of Consumer Research, 15:139-168.

BMR (Bureau of Marketing Research). 2012. Household Income and Expenditures Patterns.

http://www.unisa.ac.za/news/index.php/2013/01/household-income-and-expenditure-patterns-bmr-releasesnew-stats/ (accessed November $24^{\text {th }} 2012$ ).

COT (City of Tshwane). 2011. Service Delivery and Budget Plan 2011-2012.

http://www.tshwane.gov.za/AboutTshwane/CityManagement/CityDepartments/Financial\%20Services/Finan cial\%20Documents/Tshwane\%20Budget/SDBIP/SDBIP\%202011-2012.pdf (accessed November 20 , 2011).

Couth, Ruth, Trois, Cathrine and Vaughan-Jones, Sophy. 2011. Modelling of Greenhouse Gas Emissions From Municipal Solid Waste Disposal in Africa. International Journal of Greenhouse Gas Control, 5(6): $1443-1145$.

D'haese,Marijke and Van Huylenbroeck,Guido. 2005. The Rise of Supermarkets and Changing Expenditure Patterns of Poor Rural Households Case Study in the Transkei Area, South Africa. Food Policy, 30(1):97113.

Dos Santos, Maria.A.O. 2011. South Africa Postgraduate Consumers' Attitude Towards Global Warming. African Journal of Business Management, 5(3): 4215-4225.

Giddens, Anthony .1984. The Constitution of Society: Outline of the Theory of Structuration. Cambridgeshire: Polity Press.

Gunders, Dana. 2012. Wasted: How America is Losing up to 40 Percent of Its Food From Farm to Fork.

NRDC.http://www.nrdc.org/policy (accessed August 31 ${ }^{\text {st }}, 2013$ ).

Gustavsson, Jenny. 2011. Global Food Losses and Food Waste. FAO. Rome: Italy. www.fao.org/docrep/014/mb060e/mb060e00.pdf (accessed June 23 ${ }^{\text {rd }}, 2011$ ).

Hammett, Daniel. 2010. Reworking and Resisting Globalising Influences: Cape Town Hip-Hop. GeoJournal.

10: $1-12$.

Hanson, Sandra. L. and Zogby, John. 2010. Attitudes About the American Dream Public Opinion. Quarterly, 74: 570 - 584.

Haron, Laily.P, and Yahaya, Nurizan. 2005.Towards Sustainable Consumption: An Examination of Environmental Knowledge Among Malaysians.International Journal of Consumer Studies,29(5): 426-436. ITC - Report. 2012. Sustainability Report - For all Tomorrows. http://www.itcportal.com/sustainability/sustainability-report-2012/sustainability-report-2012.pdf (accessed November $\left.21^{\text {st }}, 2012\right)$.

Jones, Kiku and Leonard, Lori.N. 2009. From Tacit Knowledge to Organisational Knowledge. Knowledge Management and Organisational Learning, :27-39.

Kaspersen, Lars. B. 2000. Anthony Giddens: an Introduction to a Social Theorist. Malden, MA: Blackwell Publishers Inc.

Kemp, Kathrine, Insch, Andrea, Holdsworth, David. K, and Knight, J. G. 2010. Food Miles: Do UK Consumers Actually Care? Food Policy, 35(6): 504-513. 
Kilsheimer, Jacqueline.C. 1993. Status Consumption: The Development and Status Implications of a Scale Measuring Motivation to Consume for Status. A dissertation submitted to the marketing faculty at Florida State University.

Le Roux, M. 2007. Our Continent Will Suffer. Daily News, 10:1-7

Marshak, Maya. 2012. Systems in Transition: From Waste to Resource. A Study of Supermarket Food Waste in Cape Town. University of Cape Town.http://srvrhldig001.uct.ac.za/R/?func=dbin-jumpfullandobject_id=88582 (accessed January $13^{\text {th }}, 2013$ ).

Mazzocchi, Mario. 2008. Statistics for Marketing and Consumer Research. London: Sage Publications.

Mcgregor, Sue .L.T. 2000.Globalising Consumer Education: Shifting From Individual Consumer Rights to Collective Human Responsibilities. Journal of Consumer Studies, 29: 437-447.

Mcgregor, Sue .L.T. 2006.ReconceptualizingRisk Perception: Perceiving Majority World Citizens at Risk from 'Northen' Consumption. International Journal of Consumer Studies, 30: 235-246.

Nahman, Anton., De Lange, Willem., Oelofse, Suzan.H.H. and Godfrey, Linda. 2012. The Cost of Household Food Waste in South Africa.Waste Management, 32(11): 2147-2153.

Nair, Chandra. 2011. Consumptionomics: Asia's Role in Reshaping Capitalism and Saving the Planet.

International Journal of Environmental Studies, 69(3):542-545.

Nelson, Valerie. 2011. Gender, generation, social protection and climate change: A thematic review. Natural Resource Institute. University of Greenwich.Westmisister. London.

NEWS24. 2013. SAA Air Chefs Dumb Food. http://www.timeslive.co.za/local/2013/01/27/saa-air-

chefs-dumps-food-report (accessed February $13^{\text {th }}, 2013$ ).

Nieftagodien, Sihaam and Van Der Berg, Servaas. 2007.Consumptions Patterns and the Black Middle Class:

The Role of Assets. Stellenbosch Economic Working Paper 2/2007. Department of Economics and Bureau for Economic Research, University of Stellenbosch.

Nikols, Fred. 2010. The Knowledge in Knowledge Management. Distance Consulting LLC.www.nickols.us (accessed March 23 ${ }^{\text {rd }}, 2012$ ).

O'cass, Aron. and McEwen, Hmily. 2006. Exploring Consumer Status and Conspicuous Consumption. Journal of Consumer Behaviour, 4(1): 25-39.

O'connor, Robert.E., Bord, Richard.J. and Fisher, Ann. 1999. Risk Perceptions, General Environmental Beliefs and Willingness to Address Climate Change. Risk Anal, 19: 461-471.

O'loughlin, Sandra. 2007. The Wearin 'o' Green. Brand Week, 48: 26-27.

Patchen, Martin. 2006. Public Attitudes and Behaviour About Climate Change: What Shapes Them and How to Influence Them. Purdue Climate Change Research Center.

http://www.purdue.edu/discoverypark/climate/assets/pdfs/Patchen\%200P0601.pdf (accessed October, $14^{\text {th }} 2010$ ).

Richins, Marsha L. \& Dawson, Scott. 1992. A consumer values orientation for materialism and its measurement: Scale development and validation. Journal of Consumer Research, 19(3): 303-316.

Rose, Jeremy and Scheepers, Rens. 2001. Structuration Theory and Information Systems Development: Frameworks for Practice. European Conference on Information Systems Development.Bled, Slovenia.

SAARF (South African advertising research foundation). 2012. Living Standards Measure.

http://www.saarf.co.za.

Salazar, Helen.A., Oerlemans, Leon. And Stroe-Biezen, Saskia. 2013. Social Influence on Sustainable Consumption: Evidence From a Behavioural Experiment. International Journal of Consumer Studies,37: 172-180.

Schiffman, Leon.G. and Kanuk, Leslie.L. 2010. Consumer Behaviour. 10th ed. New Jersey: Pearson Prentice Hall. 
Shields,Peter., Dervin, B., Mitchell, W., and Goswami, D. 1996. Telecommunication Privacy From the Perspective of Residential Users: A Preliminary Exploration. International Association for Mass Communication Research, Communication Technology Policy Section, Sydney, Australia, August: 18-22. Sivanathan, Niro and Pettit, Nathan.C.2010. Protecting the Self Through Consumption: Status Goods as Affirmational Commodities. Journal of Experimental Social Phycology, 46: 564-570.

Smith, J. 2003. The End of Over-Consumption: Towards a Lifestyle of Moderation and Self-Restraint. The Ecologist, 33: 61.

Spaargaren,Gert. 1997. The Ecological Modernisation of Production and Consumption. Doctoral thesis $\mathrm{PhD}$. Lanbouw Universiteit: Wageningen.

Stone, George., Barnes, James. H. and Montgomery, Cameron. 1995. ECOSCALE: A Scale for the Measurement of Environmentally Responsible Consumers. Psychology and Marketing, 12(1995): 595-612. Stuart, Tristan. 2009. Waste - Uncovering the Global Food Scandal. London: Penguin.

Sundblad, Eva.L. 2008. People's Knowledge About Climate Change: Uncertainty as a Guide to Future Commitments.Department of Psychology, University of Gothenburg, Gothenburg, Sweden.

United nations population divisions. (UNPDA) 2009.Mapping Population growth and climate change hotspots. [Online] Available from: http://populationaction.org/wpcontent/uploads/2011/12/mapping_climate_change.pdf (accessed December $12^{\text {th }}, 2012$ ).

Walker, Gabrielle. and King, David. 2008. The Hot Topic. London: Bloomsbury. Wills, Judith. 2008.The Green Food Bible. Germany: Transworld publishing.

WORLD BANK. 2013. Infographic: What Climate Change Means for Africa and Asia. http://www.worldbank.org/en/news/feature/2013/06/19/what-climate-change-means-africa-asia-coastal-poor (accessed October $12^{\text {th }}, 2013$ ).

WWF. 2012. Living planet report 2012: Biodiversity, Biocapacity and Development. Produced in collaboration with the Global Footprint Network and the Zoological Society of London. Gland, Switzerland. 